\title{
Pembuatan pupuk organik dari limbah agro industri sebagai alternatif pengganti pupuk sintetis
}

\author{
Komalasari, Evelyn $\mathbb{D}^{\infty}$, Edy Saputra ${ }^{\circledR}$, \& Syelvia Putri Utami \\ Universitas Riau \\ *komalasari@lecturer.unri.ac.id
}

\begin{abstract}
Abstrak. Limbah dari pertanian dan peternakan pada kawasan yang masyarakatnya bermata pencaharian sebagai petani ataupun peternak akan menimbulkan permasalahan lingkungan jika dibiarkan terus menerus tanpa adanya pengolahan terhadap limbah tersebut. Salah satu metode pengolahan limbah agro industri adalah pupuk organik. Pupuk organik adalah pupuk yang diproduksi dari materi makluk hidup seperti pelapukan sisa-sisa tanaman, hewan dan manusia. Pupuk organik ini dapat beruapa padatan dan cairan. Kandungan yang terdapat pada pupuk ini lebih kepada bahan organik dari pada kadar haranya. Penggunaan pupuk organik ini dapat meningkatkan perkembangan tumbuhan dan dapat mengurangi efek samping dari pupuk berbahan baku kimia yang lebih mahal. Pupuk organik dapat dibuat secara mandiri dan berkelompok dan lebih ramah lingkungan dan ekonomis dibandingkan pupuk sintetis. Tujuan kegiatan ini adalah untuk melatih keterampilan masyarakat pedesaan untuk membuat pupuk organik dengan menggunakan limbah agro industri mereka secara mandiri. Pengabdian dilaksanakan di Kecamatan Rambah Hilir Desa Pasir Utama Kabupaten Rokan Hulu Provinsi Riau. Proses pembuatan pupuk organik adalah dengan mencampur kotoran sapi dan cacahan jerami padi kemudian disiram dengan EM4 yang sudah diaktifkan dengan larutan air gula merah. Campuran ini kemudian didiamkan selama 4 minggu dan setiap 3 hari diaerasi agar proses fermentasinya berjalan baik. Metode yang digunakan dalam kegiatan adalah mengadakan pelatihan dan penyuluhan mengenai Teknologi pembuatan pupuk organik dari limbah agro industri masyarakat Desa Pasir Utama. Kegiatan ini juga mendukung program pemerintah untuk mendorong pertumbuhan pemanfaatan kembali limbah agro yang akan meningkatkan produktifitas pertanian masyarakat pedesaan.
\end{abstract}

Kata kunci: agro industri; limbah; pupuk organik

\begin{abstract}
Farm and agro wastes from area which population has their livehood from farming and agriculture will result in the environmental and health issues if there is lack treatment on those wastes. One of the solutions to overcome these problems is to convert farm and agro wastes into organic fertilizer, which is produced from living substances weathering (plants and animals). Organic fertilizers are available in the form of solid or liquid and contain a lot of organic materials than nutrient levels, thus can improve plant growth. Other advantages of organic fertilizer are cheaper than synthetic ones, environmentally friendly, and are able to decrease negative effects of chemical fertilizers. Organic fertilizer can be made individually or in group of people. The objectives of this activity are to introduce the knowledge and train rural community of Kecamatan Rambah Hilir, Desa Pasir Utama Kabupaten Rokan Hulu, Provinsi Riau in making organic fertilizer using farm and agro wastes. The methods use in this activity are through socialization and training on making organic fertilizer from farm and agro wastes to Desa Pasir Utama community. Organic fertilizer was made by mixing cow manure with straw cuts, followed by addition of palm sugar activated effective microorganisms 4 (EM4). The mixture was left to incubate for 4 weeks and aerated every three days to allow good fermentation. This community service activity supports government program in encouraging growth of reusing farm and agricultural wastes that will increase agricultural productivity of rural community.
\end{abstract}

Keywords: agro industrial wastes; alternative fertilizer; organic compost

To cite this article: Komalasari, Evelyn, E. Saputra, \& S. P. Utami. 2019. Pembuatan pupuk organik dari limbah agro industri sebagai alternatif pengganti pupuk sintetis. Unri Conference Series: Community Engagement 1: 506510 https://doi.org/10.31258/unricsce.1.506-510

(C) 2019 Authors

Peer-review under responsibility of the organizing committee of Seminar Nasional Pemberdayaan Masyarakat 2019 


\section{PENDAHULUAN}

Kondisi umum wilayah Desa Pasir Utama merupakan dataran rendah dimana sebagian besar tanahnya merupakan tanah merah dengan tekstur tanah lempungan. Desa Pasir Utama termasuk dalam wilayah Kecamatan Rambah Hilir Kabupaten Rokan Hulu. Jarak Desa ke ibukota kecamatan adalah 15 km dan 20 km dari ibukota kabupaten.. Sedangkan jarak tempuh dari Pekanbaru ke Desa Pasir Utama adalah 4 jam 14 menit atau $\pm 176,4 \mathrm{~km}$.

Desa Pasir Utama dipimpin oleh seorang Kepala Desa. Dalam menjalankan tugasnya, Kepala Desa dibantu oleh seorang Sekretaris Desa dan beberapa Kepala Seksi (Kasi). Ada delapan (8) Kasi yang berfungsi di Desa Pasir Utama yaitu: Kasi Pemerintahan, Kasi Pembangunan, Kasi Pemberdayaan Masyarakat, Kasi Kesejahteraan Rakyat, Kasi Umum, Kasi Keuangan, Kasi Perekonomian dan Kasi Data dan Informasi. Selain itu ada 3 dusun di lingkungan Desa Pasir Utama yang masing-masing dipimpin oleh seorang Kepala Dusun yaitu Dusun Randu Agung, Dusun Suka Dana dan Dusun Tanjung Sari.

Jumlah penduduk sebanyak 4.101 jiwa dengan 850 Kepala Keluarga. Sebagian besar hanya tamat SD yaitu sekitar 1500 orang, dan yang tamat SMA sekitar 500 orang, sedangkan yang tamat sarjana hanya sekitar 40 orang

Mayoritas masyarakat di desa Pasir Utama adalah suku Jawa dan Melayu. Dalam aktivitas sehari-hari mereka sangat terbuka terhadap masyarakat pendatang. Masyarakat masih memegang teguh adat istiadat daerah. Sebagian besar penduduk adalah petani dan bercocok tanam dengan jenis tanaman keras, misalnya karet dan kelapa sawit.

Selain itu ada juga yang berdagang dan menjadi pegawai negeri sipil. Selain bertani, sebagian masyarakat juga beternak sapi, ayam kampung, bebek dan angsa. Ada sekitar 750 ekor sapi, 5000 ekor ayam kampung, 1400 ekor bebek dan 105 ekor angsa di Desa Pasir Utama yang dikelola secara perorangan dan kelompok.

Dengan jumlah petani dan peternak yang mencapai lebih dari 50\%, Desa Pasir Utama mempunyai potensi limbah peternakan (kotoran) dan limbah pertanian (jerami dan sekam padi) serta limbah perkebunan yang besar. Selama ini sebagian besar limbah tersebut hanya dibiarkan begitu saja, terutama limbah peternakan.

Limbah peternakan (kotoran sapi) dan juga ternak lainnya dapat dimanfaatkan sebagai bahan baku pembuatan pupuk organik yang nantinya akan memberikan manfaat lebih untuk lahan pertanian yang ada di Desa Pasir Utama dan wilayah sekitarnya.

Kandungan unsur hara yang ada dalam kotoran sapi berguna untuk perkembangan tanaman. Satu ekor sapi dapat menghasilkan pupuk kompos dari kotorannya sebesar 23,6 kg/hari. Kandungan unsur hara yang terdapat dalam kotoran sapi adalah Nitrogen, Fosfor dan juga Kalium yang sangat diperlukan sebagai nutrisi oleh tanaman. Penggunaan pupuk organik sebagai bagian untuk mengembangkan lahan pertanian telah digiatkan guna mengurangi pengaruh penggunaan pupuk berbahan kimia agar terjalin eco-agro industri yang baik.

Beberapa teknologi telah dikembangkan untuk memperoleh pupuk organik dengan cepat yakni, bokashi, kompos dan lainnya. Teknologi perpaduan antara pupuk kandang dan dekomposer seperti EM4 dilakukan agar dekomposisi berlangsung lebih cepat. Bukan hanya dengan pupuk kandang, tapi dapat juga dikombinasikan dengan limbah pertanian seperti jerami padi atau antara arang sekam dan pupuk kandang (Wibowo, 2013).

Kotoran sapi dan ternak lainnya yang dibiarkan terus tanpa adanya perlakuan tertentu akan mengganggu kenyamanan dan lingkungan. Oleh karena itu, pemanfaatan dan pengolahan kotoran ternak menjadi pupuk organik akan membantu para petani untuk mengembangkan lahan pertaniannya. Hal ini tentunya akan meningkatkan produksi pertanian bagi masyarakat dan akan meningkatkan kehidupan ekonomi masyarakat.

Dengan adanya pelatihan pembuatan pupuk organik dari limbah peternakan dan pertanian ini, maka masyarakat Desa Pasir Utama dapat memproduksi pupuk organik secara mandiri dan berkelompok untuk kebutuhan masyarakat pertanian, serta dapat mengembangkan potensi daerah dalam hal peternakan dan pertanian di daerah tersebut. Selain itu manfaat yang diperoleh yaitu dapat menggunakan pupuk organik yang lebih aman terhadap lingkungan dan dapat mengurangi biaya pengolahan pertanian mereka.

\section{Kajian Literatur dan Pengembangan Hipotesis}

Daerah pertanian dan pertanian berpotensi untuk meningkatkan kesejahteraan masyarakat sekitar namun di sisi lain juga akan memberikan dampak buruk bagi lingkungan. Dampak dari pertanian dan peternakan ini akan menimbulkan limbah pra dan pasca panen. Limbah pasca panen terbagi menjadi limbah sebelum diolah dan setelah diolah atau limbah industri pertanian. Limbah pertanian adalah material-material biologi yang terkumpul sebelum atau sementara hasil utamanya diambil untuk keperluan konsumtif.

Jenis limbah pertanian dikelompokkan menjadi tiga kelompok menjadi limbah padat, cair dan gas. Limbah padat ini diantaranya: daun-daun kering, jerami, sabut serta tempurung kelapa, kulit dan tulang dari ternak 
potong, bulu ayam, ampas tahu, jeroan ikan dan sebagainya. Jika limbah ini dibiarkan tanpa ada perlakuan tertentu akan menimbulkan keadaan tidak higienis bahkan bisa membawa berbagai jenis kuman penyakit.

Limbah cair dari industri pertanian mengandung banyak bahan organik yakni karbohidrat, lemak dan protein. Limbah ini mudah sekali busuk dan menimbulkan polusi udara dan air. Sedangkan limbah gas dikeluarkan pada saat pengolahan hasil-hasil pertanian misalnya gas yang timbul berupa uap air pada proses pengurangan kadar air selama proses pelayuan teh serta proses pengeringannya. Limbah padat, cair dan gas ini dapat diolah menjadi pupuk dan makanan ternak.

Dampak limbah agro industri ini akan memberikan gangguan terhadap kehidupan biotik, keindahan, kesehatan. Akibat dari air limbah ini dapat menyebabkan kehidupan di dalam air yang membutuhkan oksigen akan terganggu. Air limbah yang mengalir perairan dapat menyebabkan kurangnya oksigen di dalam air sehingga dapat menyebabkan adanya zat beracun yang berada di dalam air limbah tersebut air limbah ini akan sulit diuraikan. Limbah cair sangat bisa berbahaya terhadap kesehatan manusia karena dapat menyebabkan penyakit yang bisa ditularkan melalui air limbah. Bahkan dapat berfungsi sebagai media pembawa penyakit yakni kolera, radang usus, hepatitis infektiosa dan skhistosomiasis. Bahkan beberapa penyakit ada yang menular melalui udara (dosenpertanian.com; Endriani et al., 2019).

\section{Kotoran Sapi}

Kotoran sapi dapat dimanfaatkan sebagai pupuk kandang yang lebih ekonomis. Kotoran sapi yang sudah kering cenderung tidak memiliki bau yang tidak menyengat. Penggunaan kotoran sapi sebagai pupuk sangat disarankan karena tidak mengandung zat kimia yang dapat mengganggu keseimbangan alam.

Kotoran sapi mengandung serat yang sangat tinggi yakni selulosa yang sangat tinggi. Kandungan unsur hara ini akan semakin meningkat jika dicampur dengan kencing sapi. Kandungan unsur haranya adalah nitrogen, fosfor dan kalium.

Berdasarkan berat tubuhnya, kadar unsur hara dalam tubuh sapi dapat berbeda-beda, seperti dibawah ini:

- Sapi dengan berat $227 \mathrm{~kg}$ mampu menghasilkan kotoran sapi dengan kandungan nitrogen sebanyak $28,1 \%$; fosfor $9,1 \%$; dan kalium sebesar $20 \%$.

- Sapi dengan berat $340 \mathrm{~kg}$ mampu menghasilkan kotoran sapi dengan kandungan nitrogen sebesar $42,2 \%$; fosfor $13,6 \%$; dan kalium $30 \%$.

- Sapi dengan berat $454 \mathrm{~kg}$ mampu menghasilkan kotoran sapi dengan kandungan nitrogen sebesar $56,2 \%$; fosfor $18,2 \%$; dan kalium $39,9 \%$.

Ketiga kandungan unsur hara ini bermanfaat besar bagi tanaman. Nitrogen dapat meningkatkan kadar protein dalam tanah, membantu proses sintesis asam amino dan protein di dalam tanaman. Fosfor membantu proses fotosintesis dan penyusunan asam nukleat dan mempercepat waktu panen tanaman. Sedangkan Kalium dapat membentuk dan mengangkut karbohidrat di dalam tubuh tanaman, mengatur pergerakan stomata, meningkatkan kekokohan batang tanaman, meningkatkan kadar karbohidrat dan gula dalam buah sehingga buah memiliki rasa manis dan meningkatkan ketahanan tanaman dari hama dan penyakit (Ginaini, 2018).

\section{Kompos}

Pupuk kompos adalah salah satu pupuk organik yang diperoleh dengan menguraikan sisa-sisa tanaman dan hewan dengan bantuan organisme hidup. Pembuatannya memerlukan material organik dan organisme pengurai berupa mikroorganisme ataupun makroorganisme. Teknologi pengomposan dapat dikembangkan secara alami, misalnya humus di hutan. Proses ini memakan waktu yang sangat lama bahkan bisa bertahun-tahun. Kemudian dikembangkanlah modifikasi penguraian dengan bantuan organisme lain sehingga dapat dilakukan dengan waktu yang lebih singkat.

Pengelompokkan jenis pupuk kompos dapat dilihat dari tiga aspek yakni proses pembuatannya, dekomposer dan dilihat dari bentuk atau fasanya. Proses pembuatan kompos dapat diperoleh secara aerob dan anaerob sedangkan dari fasanya dapat berupa padat dan cair.

Pupuk kompos dapat meningkatkan kemampuan tanah untuk menyimpan air sebagai cadangan bahkan dapat menggemburkan tanah agar tidak terlalu solid. Secara kimiawi, pupuk kompos dapat meningkatkan kapasitas tukar kation dalam tanah. Hal ini berfungsi melepaskan unsur-unsur penting agar dapat dengan mudah diserap oleh tanaman. Kompos yang baik memiliki ciri-ciri (Risnandar, 2018): baunya sama dengan tanah, tidak berbau busuk, warna coklat kehitaman, gembur seperti tanah, jika dimasukkan ke dalam air seluruhnya tenggelam dan air tetap jernih tidak berubah warna dan jika diaplikasikan pada tanah tidak memicu tumbuhnya gulma 


\section{METODE PENERAPAN}

Pelaksanaan kegiatan ini terdiri dari beberapa tahapan, yakni:

1. Persiapan

Tahap persiapan meliputi: koordinasi pelaksanaan kegiatan dengan pemerintah daerah setempat (Kepala Desa), penyiapan bahan-bahan yang akan digunakan untuk pembuatan kompos organik.

2. Pengaktifan EM4 (Effective Microorganisme 4)

Bahan baku terdiri dari EM4 sebanyak 1 liter, $0,5 \mathrm{~kg}$ gula merah, 4 buah nenas dan air sebanyak 38 liter. Prosedur pengaktifan EM4 yaitu : 0,5 kg gula merah dilarutkan dengan 1 liter air ditambah dengan sari buah nenas (buah nenas dicampur dengan 38 liter). Setelah campuran homogen ditambahkan EM4 kemudian diaduk lalu ditutup dalam wadah tertutup selama 1 minggu (agrotani.com).

3. Proses pembuatan pupuk organik dari limbah peternakan dan EM4 aktif

Limbah peternakan yang dipergunakan pada kegiatan pengabdian ini adalah kotoran sapi. Prosedur dimulai dengan mencampurkan kotoran sapi dan jerami padi yang telah dicacah dengan rasio 50:50 (rasio dapat menyesuaikan 60:40 atau 40:60) dengan total keduanya adalah $100 \mathrm{~kg}$. EM4 yang dipergunakan untuk campuran tersebut adalah $100 \mathrm{ml}$. EM4 disiramkan ke campuran kotoran sapi dan jerami padi tersebut dengan perlahan. Kompos kemudian ditutup rapat minimal 4 minggu. Setiap 3 hari, campuran tersebut dibalik untuk aerasi. Jika tumpukannya sudah tidak panas maka kompos dari kotoran sapi sudah jadi (Sulistyo, 2017).

\section{HASIL DAN KETERCAPAIAN SASARAN}

Kegiatan pengabdian kepada masyarakat ini dilaksanakan kepada masyarakat di Desa Pasir Utama Kecamatan Rambah Hilir Kabupaten Rokan Hulu, Provinsi Riau. Pelaksanaan pengabdian ini ditujukan kepada masyarakat sekitar, terutama kelompok bina desa, tim penggerak PKK dan pemuka masyarakat. Tujuan kegiatan ini dilakukan adalah:

1. Meningkatkan pengetahuan dan pemahaman masyarakat tentang cara membuat pupuk organik dari limbah peternakan dan pertanian.

2. Memberikan wawasan terhadap masyarakat mengenai manfaat penggunaan pupuk organik yang lebih ramah lingkungan dibandingkan pupuk sintetis

3. Merupakan salah satu pelaksanaan Tri Dharma Perguruan Tinggi.

Brosur/leaflet diberikan ke masyarakat untuk membantu mereka agar lebih mudah mempelajari dan memahami proses pembuatan pupuk organik dari limbah agro industri. Setelah pemaparan tentang proses pembuatan pupuk organik dari limbah agro industri, masyarakat ditunjukan contoh bahan baku, EM4 yang sudah aktif sampai hasil pupuk organik yang sudah dibuat. Pupuk organik yang sudah dibuat dikemas dalam beberapa bungkusan dan kemudian dibagikan ke Kepala Desa sebagai simbol untuk kemudian sisanya diberikan kepada peserta kegiatan pengabdian. Secara umum, masyarakat yang ikut hadir pada pelatihan ini memberikan tanggapan positif dan merespon dengan baik. Beberapa peserta pelatihan bertanya mengenai prosedur pembuatan pupuk organik dan ikut berpartisipasi pada demonstrasi pembuatan pupuk organik tersebut. Peserta begitu antusias, hal ini terlihat dengan dilanjutkannya diskusi antara tim pengabdian dengan kelompok bina desa, ketua tim penggerak PKK dan Kepala Desa tentang tindak lanjut yang perlu dilakukan dalam pemanfaatan limbah peternakan dan pertanian agar lebih bernilai jual.

Ada beberapa faktor yang mempengaruhi dalam melaksanakan kegiatan pengabdian ini, yaitu faktor penghambat dan faktor pendukung.

1. Faktor penghambat

Masyarakat sedikit terganggu dengan bau dari kotoran sapi, tetapi setelah proses fermentasi maka bau tersebut akan hilang. Penghambat lainnya adalah kekhawatiran masyarakat mengenai cara memperoleh EM4 yang dijual hanya di tempat-tempat tertentu. Selain itu hambatan lain yaitu ternyata buah nanas tidak terlalu banyak terdapat di daerah tersebut, tapi hal ini dapat diatasi dengan menggantinya dengan buah pepaya. Namun demikian, masyarakat sangat tertarik untuk membuat pupuk organik dari limbah agro industri ini. 
2. Faktor pendukung

Kepala desa beserta jajarannya, pemuka masyarakat, dan ketua tim penggerak PKK serta mahasiswa Kukerta 2019 di Desa Pasir Utama dan desa di sekitarnya turut mendukung pelaksanaan pengabdian pembuatan pupuk organik dari limbah agro industri dengan menggiatkan informasi ini kepada masyarakat sekitar. Pemuka masyarakat juga mengharapkan adanya pengabdian lain untuk dapat menambah wawasan dari masyarakat desa Pasir Utama agar lebih terbuka, modern dan mandiri.

\section{KESIMPULAN}

Pelaksanaan evaluasi kegiatan telah dilaksanakan di masyarakat Desa Pasir Utama Kecamatan Rambah Hilir Kabupaten Rohul Riau, namun data yang diperoleh masih belum diolah dan dikembangkan. Evaluasi dilakukan terkait minat dan respon masyarakat terhadap pelatihan ini. Tim pengabdian UNRI bersedia datang dan memberikan jasa konsultasi jika ada hal-hal yang diperlukan atau ada pertanyaan dari peserta pelatihan. Secara umum dapat disimpulkan bahwa masyarakat Desa Pasir Utama sangat antusias dengan adanya pelatihan yang diberikan oleh akademis kampus kepada mereka. Tolok ukur keberhasilan kegiatan ini adalah adanya minat dari peserta pengabdian ini untuk mencari tahu dan semakin memahami cara memanfaatkan limbah peternakan dan pertanian menjadi lebih bernilai. Dari antusias peserta yang terlihat pada pengabdian, diharapkan dapat mempraktekkan pengetahuan yang diperoleh dan dapat berbagi ilmu kepada masyarakat yang lain.

\section{UCAPAN TERIMA KASIH}

Penulis mengucapkan terimakasih kepada LPPM UNRI yang telah memberi dukungan dalam bentuk hibah pengabdian kepada masyarakat UNRI 2019 dengan nomor kontrak 462/UN.19.5.1.3/01.03/2019. Penulis juga mengucapkan apresiasi dan terimakasih yang sebesar-besarnya kepada masyarakat Desa Pasir Utama Kecamatan Rambah Hilir Kabupaten Rokan Hulu Riau, atas keramah-tamahannya dalam menerima tim pengabdian masyarakat Jurusan Teknik Kimia Universitas Riau. Selain itu penulis juga mengucapkan terimakasih kepada mahasiswa Kuliah Kerja Nyata 2019 di desa Pasir Utama yang turut membantu dan berpartisipasi dalam kegiatan pengabdian ini.

\section{DAFTAR PUSTAKA}

Endriani, R., E. Nazriati, \& L. P. Sembiring. 2019. Peningkatan peran serta masyarakat dalam upaya pencegahan dan pengobatan tuberkulosis di Sentajo Raya, Kabupaten Kuantan Singingi. Riau Journal of Empowerment 2(1): 2126. https://doi.org/10.31258/raje.2.1.16

Ginaini. 2018. 9 Manfaat Kotoran Sapi Bagi Pertumbuhan Tanaman. https://manfaat.co.id/manfaat-kotoran-sapi Diakses pada tanggal 22 Januari 2019.

Ginaini. 2018. Pengertian Limbah Pertanian, Jenis, Dampak, Penanganan, dan Contohnya. https://dosenpertanian.com/limbah-pertanian Diakses pada tanggal 24 Januari 2019.

Risnandar, C. 2018. Jenis-jenis Pupuk Kompos. https://alamtani.com/pupuk-kompos/ Diakses pada tanggal 20 Januari 2019.

Sulistyo, J. 2017. Cara Membuat Pupuk Kandang dari Kotoran Sapi dengan EM4. https://www.kambingjoynim.com/cara-membuat-pupuk-kandang-dari-kotoran-sapi-dengan-em4/ Diakses pada tanggal 20 Januari 2019.

Wibowo, A. 2013. Membuat Pupuk Organik dari Limbah Pertanian dan Ternak. Teknologi Pertanian, http://pertanian.magelangkota.go.id/informasi/teknologi-pertanian/125-membuat-pupuk-organik-dari-limbahpertanian-dan-ternak. Diakses pada tanggal 20 Januari 2019. 